2006

\title{
Legal Representation of Birth Parents and Adoptive Parents
}

Elizabeth Samuels

University of Baltimore School of Law, esamuels@ubalt.edu

Follow this and additional works at: http://scholarworks.law.ubalt.edu/all_fac

Part of the Family Law Commons, and the Juvenile Law Commons

\section{Recommended Citation}

Legal Representation of Birth Parents and Adoptive Parents, 9 Adoption Quarterly 73 (2006)

This Article is brought to you for free and open access by the Faculty Scholarship at ScholarWorks@University of Baltimore School of Law. It has been accepted for inclusion in All Faculty Scholarship by an authorized administrator of ScholarWorks@University of Baltimore School of Law. For more information, please contact snolan@ubalt.edu. 


\section{LEGAL INTERSECTIONS}

\section{Legal Representation of Birth Parents and Adoptive Parents}

Elizabeth Samuels

Domestic infant adoption has two primary goals: (1) preventing the unnecessary separation of family members by ensuring that birth parents make informed and deliberate decisions and (2) protecting the finality of adoptive placements. Ideally, these goals are complementary and can be balanced. There is, however, a danger of the second goal eclipsing the first. Many state laws appear to value an increase in infant adoptions over the goal of encouraging careful deliberation. Most domestic infant adoptions involve powerful market forces as well as powerful emotional pressures, and they occur in the context of a national commitment to encourage adoptions of older children and children with special needs. Infant adoption service providers' livelihoods or profits generally depend on successfully arranging adoptions for their primary clients, who, for the most part, are relatively prosperous, well-established, and socially favored married couples whose desires to bear children have been thwarted by infertility. In their efforts to adopt, these

Elizabeth Samuels is Associate Professor of Law, University of Baltimore Law School.

This paper is adapted from Elizabeth I. Samuels" "Time to Decide? The Laws Gov" erning Mothers' Consents to the Adoption of Their Newbom Infants," 72 Tenn. L. Rev. 509 (2005), with the permission of the Tennessee Law Review Association, Ine.

Adoption Quarterly, Vol. 9(4) 2006

Available online at hitp:/aq. haworthpress.com

(C) 2006 by The Haworth Press, Inc. All rights reserved. doi: $10.1300 / 5145$ v9no4 05 
couples often face great difficulties and pay high fees. By contrast, birth parents in the stressful situations that lead them to consider placing their infants for adoption are not an organized group and are relatively powerless and socially disfavored. This article examines the role that legal representation of these parties may or may not play in independent adoptions in promoting the deliberate decision making and finality that characterize ethically and humanely conducted adoptions.

\section{LEGAL REPRESENTATION ISSUES}

When birth parents consent to adoption, they are giving up their fundamental right to parent and are participating in a legal process in which a court determines whether it is in the best interest of the child to legally dissolve the child's birth family ties and to establish a new set of family relationships. Given the importance of this process for all the individuals affected by it, it is crucial that both birth and adoptive parents understand the legal process, including the nature of their rights and the various options a vailable to them. Representation by an attorney, of course, can provide the participants in the process with expert legal guidance. In independent adoptions, the most common type of domestic infant adoption, a number of questions arise about legal representation. Is it permissible for one attorney to represent both the adoptive and birth parents? Should the parties be required to have separate representation? Should the parties be required to have separate representation only in cases in which birth parents are minors or under some other disability? Although this article focuses on independent adoptions, concerns about legal representation for birth parents also arises in agency-arranged adoptions because of the likelihood of conflicts of interest between an agency's responsibility to birth parents and the agency's commitment to prospective parents who are paying the agency's fees.

In an informal opinion in 1987, the American Bar Association (ABA) Standing Committee on Ethics and Professional Responsibility concluded that an attorney may not ethically represent both birth and adoptive parents.' This opinion, which would apply to both agency and independent adoptions, is not binding on all states, however, and the laws on dual representation vary throughout the country. Dual representation is expressly permitted in at least two states, Kansas, ${ }^{2}$ and California. In California, an attorney must have written consent of the parties before engaging in dual representation, and the attorney may not engage in dual representation "whenever a birth parent displays the slightest 
reason for the attorney to believe any controversy might arise." 3 If a conflict arises after an attorney begins dual representation, the attorney must withdraw under the California statute. In addition, birth parents have the right to an independent attorney to whom prospective adoptive parents may be required to pay reasonable attorney's fees up to $\$ 500$ unless a higher fee is agreed to by the parties. On the other hand, dual representation is expressly prohibited by statutes in a number of states, including Kentucky, Maine, Maryland, Michigan, Minnesota, New York, and Wisconsin. Florida allows lawyers to serve as intermediaries in independent adoptions, but prohibits intermediaries from providing legal representation or advice to birth parents. ${ }^{4}$

In some states, separate representation is required only in some circumstances. Louisiana requires separate representation in all private adoptions, while a small number of states, including Kansas, Maryland, Montana, and Vermont, require separate representation for minor parents. ${ }^{5}$ Alabama and Arkansas require appointment of a guardian ad litem for a minor birth parent. ${ }^{6}$ Maine requires the court to appoint an attorney for an indigent birth parent who is a minor, unless the birth parent refuses or "the court determines that representation is unnecessary." New Hampshire requires representation if a birth parent who has not yet relinquished parental rights is incompetent, mentally ill, or is a person with mental retardation. ${ }^{8}$ In practice, when separate representation is not required by law, birth parents generally are unrepresented. There are potential risks for birth parents without representation, but as the debates about representation reveal, there also are risks when they are represented either by prospective adoptive parents' attorneys or by separate counsel paid for by adoptive parents. ${ }^{9}$

Dual representation proponents argue that a conflict of interest between the parties is "often more hypothetical than real" because "both parties are usually strongly in favor of the adoption." 10 Writing about how dual representation is permitted under some circumstances in California, lawyer Jed Somit also contends that separate representation increases costs and introduces the specter of runaway fees if the adoptive parents are liable for the birth parents' attorneys' fees without limit. ${ }^{11}$ Separate representation "makes or at least stigmatizes as adversarial what is ideally a cooperative process." He offers the disheartening additional argument that, despite its dangers, dual representation may be preferable to separate representation because birth parents' attorneys are usually paid less and may provide inferior representation. In any event, it is claimed that "experienced adoption attorneys avoid dual representation" in the "[m]any situations" in which it is not suitable. If dual 
representation has been undertaken and a conflict arises, the attomey should withdraw and the parties can then obtain separate counsel, or, as expressly permitted in some state court decisions, the attorney may terminate the dual representation and choose which party to continue representing. ${ }^{12}$

Opponents of dual representation, including the $\mathrm{ABA}$, maintain there are "inherent conflicts" that "cannot be reconciled" between the birth parents" right to withhold or revoke consent and the prospective adoptive parents' goal of securing consent, and avoiding revocation. In this view, dual representation violates Rule 1.7(a) of the ABA Model Rules of Professional Conduct, which prohibits representing a client "if the representation of [that] client will be directly adverse to another client," unless the attorney reasonably believes it will not be and each client consents after consultation. ${ }^{13}$ (While the Model Rules are not binding on any jurisdiction, most jurisdictions have adopted some version of them.) A secondary issue regarding dual representation may arise, of course, if the birth mother's and the birth father's interests conflict, when, for example, the birth father decides to contest the adoption. If an attorney believes, however, that the birth parents' interests are not in conflict, and both the birth parents consent, the attorney may represent them both. When only the birth mother is represented by an attorney, only she will enjoy the benefit of independent legal advice.

Conflicts between birth and adoptive parents may arise over not only the ultimate issue of consent, but also issues involving financial support during pregnancy and birth, the timing of consents and of placement of the child with the prospective adoptive parents, and, if post-adoption contact with birth parents is contemplated by the parties, the nature and extent of future contact. The ability of parties to knowingly consent to dual representation is doubted, given the emotional and stressful nature of their situations: "It is difficult to believe [that they] can really grasp the essential point: that the same lawyer is advising the birth mother and the couple, who desperately want to obtain her child." 14 Also, consent cannot be obtained from two interested parties: that is, the infant child being adopted and the state. Finally, the Model Rules indicate that in any event, the costs for services performed by two lawyers should not exceed the cost of the same services provided by one lawyer. "If the savings by retaining a single attorney is obtained at the sacrifice of adequate, thorough representation of each party's separate interest, it would seem a dubious benefit."'15

Does any expression of doubt or ambivalence by a birth parent mean that the attorney must cease dual representation? Will a birth parent's 
interests be compromised if a conflict arises and dual representation ceases at a time when a birth parent's right to revoke consent is about to expire? If there has been dual representation, will adoptive parents be vulnerable to a challenge to the adoption based on a claim of undue influence or duress? If a conflict arises, is it permissible for the attorney to continue to represent the adoptive parents who are paying for the legal services, even though the dual representation has "removed the communications of the parties to one another and to the attorney from the privileged category?" 16 If it is not permissible for the attorney to continue to represent one of the parties, will costs considerably increase in situations in which dual representation has been undertaken and later terminated?

Those who favor requiring separate representation, whether in all cases or in a limited class of cases, emphasize the important nature of the adoption proceeding, the typical imbalance of power between birth parents and adoptive parents, the possibility of conflicts of interest, and the fact that many birth mothers change their minds after the birth. Lawyers Katherine $\mathrm{G}$. Thompson and Douglas $\mathrm{H}$. Reiniger, for example, argue for separate representation because most mothers are young, lack financial resources, and are in such stressful, painful situations that their "capacity for rational decision-making at this time is not completely reliable." 17 Prospective adoptive parents, in contrast, tend to be "somewhat older than most birth parents," are "usually well above average in income and education," and are thus more financially able to retain an attorney. ${ }^{18}$

Even with separate representation, there is a danger of birth parents' attorneys being too closely associated with the prospective adoptive parents or their attorneys if the birth parents' attorneys have been recommended by the adoptive parents' attorneys or are paid by the adoptive parents. The danger is described in a proposed model disclosure form:

There is a risk that since the money is coming from [Adopting Parents] through [Adopting Parents" Attorney's] office, "I will be more attentive to their needs, and more cooperative with that law office, than I am to your interests. .. . However, I am an experienced attorney, and I believe I can represent the interests of my clients notwithstanding getting paid (or not getting paid) by another.'19

A similar concern was articulated by an Ohio appellate court: "We are compelled to emphasize that while there is no evidence of any impropriety as to the fee arrangement here, such may not always be the re- 
sult. The better practice is that the birth mother be solely responsible for her fees, or if the adoptive parents agree to the payment of the birth mother's attorney fees, such payments must not be contingent upon the outcome of placement or adoption." 20 In a case involving an analogous issue, a justice of the North Dakota Supreme Court noted in a concurrence: "[T]he adoption agency is in the business, if you will, of obtaining babies for adoption.... While an agency's advising or attempting to persuade a parent to consent to termination of parental rights does not constitute duress . . . a mother contemplating termination of her parental rights needs distance from the agency... . The means available to insure that distance is an attorney ... not hired or paid by the adoption agency." 21 Reflecting a similar concern is the advice that birth parents obtain attomeys through referrals independent of adoptive parents' attorneys. "[T]he attorney for the adoptive parents should have little or no control over what lawyer represents the birth parent(s). ... If the adoptive parents' attorney does participate in the selection process, he should give the birth parent at least three names of experienced attorneys ..."22

\section{RECOMMENDATIONS}

To help ensure that the goals of adoption are successfully met, states' adoptions laws should make clear that attorneys may not simultaneously represent adoptive parents and birth parents. Attorneys and other adoption services providers should be required to clearly inform birth parents, orally and in acknowledged writings, that birth parents' interests are not and may not be represented by attorneys who represent prospective adoptive parents. As provided by many states and as recommended by the Uniform Adoption Act, ${ }^{23}$ birth parents should be clearly informed that they have a right to have legal representation and that their representation may be paid for by the prospective adoptive parents.

It is not likely that many states will decide to require separate representation for birth parents, despite its benefits in both independent and agency-arranged adoptions, because of the costs that are involved either for the adoptive parents or the state. There is perhaps a better chance that states will follow the lead of a small number of states, and the recommendation of the Uniform Adoption Act, ${ }^{24}$ and will provide that parents who are minors may not give valid consent to the adoption of their children unless they have been advised by a lawyer who is not representing adoptive parents or an adoption agency. In any event, even though legal representation makes it more likely birth parents will un- 
derstand their legal rights, there remains a risk of a conflict of interest, as discussed earlier, when the birth parents' attorney is paid by prospective adoptive parents. If more birth parents decide to place their children for adoption, more work will be available for all attorneys involved in adoptions.

Regardless of possible conflicts of interest, it is difficult to legislate the timing and quality of representation that birth parents receive. The Kansas Court of Appeals found that its state law requiring representation for young birth parents had been complied with in a case in which the prospective adoptive parents" attorney "less than an hour before the scheduled meeting [for signing consents] . . realized that under Kansas law, [the birth parents] were to be provided independent legal counsel." 25 An attorney whose office was in the same suite was enlisted and briefed for five minutes. He then advised the birth parents and took their consents, satisfying the requirement that "a minor parent shall have the advice of independent legal counsel as to the consequences of the consent or relinquishment prior to its execution," and the attorney "shall be present at the execution" of consent. ${ }^{26}$ As a concurring North Dakota Supreme Court justice wrote, "[m]eeting with the client immediately before a termination of parental rights hearing for the first and only time does not allay the perception of lack of independent counsel. It fortifies my concern that providing counsel under such circumstances is but a perfunctory observance of a meaningless ritual." 27 Separate legal representation for birth parents cannot alone guarantee adoption practices that prevent unnecessary family separation and provide finality, Nor is separate representation likely to become the rule in domestic infant adoptions. But states and adoption service providers can and should take at least the simple steps recommended here to ensure that legal services will play as helpful a role as possible in promoting ethical and humane adoption practices.

\section{NOTES}

1. See ABA Comm. on Ethics and Prof'l Responsibility, Informal Op. 1523 (1987).

2. In re Adoption of Baby Girl T., 21 P.3d 581, 589 (Kan. Ct. App. 2001) (noting that dual representation is permitted if certain conditions are inet).

3. Cal. Fam. Code $\$ 8800(\mathrm{c})$.

4. Ky. Rev. Stat. Ann. \& 199.492 (Michie 1998); Me. Rev. Stat. Ann. tit. 18-A, \& 9-106(a) (West 1964); Md. Code Ann., Fam. Law \& 5-323(e) (1999); Mich. Comp. Laws Ann. \$ 722.956(c)(ix) (West 2002); Minn. Stat. Ann. $\$ 259.47$ (West 2003); N.Y. 
Soc. Serv. Law \$ 374(6) (McKinney 2003); Wis. Stat. Ann. \$ 48.837(8) (West 2003); Fla. Stat. Ann. $\$ 63.032,63.085$ (West 1997).

5. La. Ch. Code Ann. art. 1121 (West 2004): Kan. Stat. Ann. \$ 59-2115 (1994); Md. Code Ann., Fam. Law \$5-323(a)(1) (appointment of counsel also required for parent rendered by disability incapable of consenting and effectively participating in proceedings); Mont. Code Ann. \& 42-2-405(2) (2003); Vt. Stat. Ann. it. 15A, \$ 2-405(c) (2002).

6. Ala. Code $\$ 26-10$ A-8 (Supp. 2004); Ark. Code Ann. 9-9-220 (Michie 2002).

7. Me. Rev. Stat. Ann. tit. 18-A, $\$ 9-106($ b)

8. N.H. Rev. Stat. Ann. \& 170-B:5(II) (2002).

9. See, for example, Pamela K. Strom Amlung, Comment, Conflicts of Interest in Independent Adoptions: Pitfalls for the Unwary, 59 U. Cin. L. Rev. 169 (1990); Linda Jean Davie, Note, Babes and Barristers: Legal Ethics and Lawyer-Facilitated Independent Adoptions, 12 Hofstra L. Rev. 933 (1984). Adoptive parents may pay birth parents' legal fees except in a number of states in which the specified expenses that adoptive parents may pay do not include legal costs. Amlung, supra, at 184 \& n. 109 .

10. Jed Somit, Independent Adoptions in California; Dual Representation Allowed, in 2 Adoption Law and Practice, supra note 6, 5.04(4)(c).

11. Id.

12. See, e.g., Arden v. State Bar of Cal., 341 P.2d 6, 11 (Cal. 1959); In re Adoption of Baby Girl H., 739 P.2d 1, 3 (Kan. Ct. App. 1987).

13. Model Rules of Prof"1 Conduct R. 1.7 (2002).

14. Katherine G. Thompson \& Douglas H. Reiniger, Private-Placement Adoptions in New York; Separate Representation Required, in 2 Adoption Law and Practice, $\$ 6.01(3)(\mathrm{b})$.

15. Id. $\S 6.01(7)$.

16. Arden v. State Bar of Cal., 341 P.2d 6, 11 (Cal. 1959), In re Adoption of Baby Girl H., 739 P.2d 1, 3 (Kan. Ct. App. 1987).

17. See Thompson \& Reiniger, supra note $x v, \$ 6.01(2)(a)$ (ii) and (iii).

18. Id. $\$ 6.01(2)(\mathrm{b})(\mathrm{i})$ and $\$ 6.01(2)(\mathrm{a})(\mathrm{ii})$.

19. Somit, supra note $x i, 5.04(3)(b)$.

20. In re Adoption of Infant Girl Banda, 559 N.E.2d 1373, 1383 (Ohio Ct. App. 1988).

21. In re D.J.H., 401 N.W.2d 694, 704 (N.D. 1987) (Levine, J., concurring specially) (citations omitted).

22. Thompson \& Reiniger, supra nole xiv, $\$ 6.01(4)(a)$.

23. Uniform Adoption Act (1994), \&\$2-204(c), 7-103(a)(7).

24. Id. $\$ 2-405(\mathrm{c})$.

25. In re Adoption of N.A.P., 930 P.2d 609, 612 (Kan. Ct. App. 1996).

26. Id., at 614.

27. In re D.J.H., 401 N.W.2d 694, 703-04 (N.D. 1987) (Levine, J., concurring specially). 